\title{
INDIAN OCEAN IMAGINARIES. \\ THE ACADEMIC TRAJECTORY OF \\ THE RATNAKARA RESEARCH GROUP
}

\author{
Esther Pujolràs-Noguer \& Felicity Hand \\ Universitat de Lleida \& Universitat Autònoma de Barcelona
}

\section{Abstract}

This article outlines the academic trajectory of the Ratnakara Research Group through a description of the research conducted in each of the financed research projects it has been awarded. Ratnakara. Indian Ocean Literatures and Cultures is the only Spanish research group that specializes in the study of the literary and cultural productions of the Indian Ocean area and has contributed to the creation and consolidation of Indian Ocean imaginaries.

Keywords: Indian Ocean, Ratnakara, Postcolonialism, Transnationalism.

IMAGINARIOS INDOCEÁNICOS.

LA TRAYECTORIA ACADÉMICA DEL

GRUPO DE INVESTIGACIÓN RATNAKARA

\section{RESUMEN}

Este artículo presenta la trayectoria académica del grupo de investigación Ratnakara mediante una descripción de la investigación llevada a cabo en cada uno de los proyectos financiados que ha conseguido. Ratnakara. Indian Ocean Literatures and Cultures es el único grupo de investigación español especializado en el estudio de las producciones literarias y culturales del Océano Índico y ha contribuido en crear y consolidar imaginarios indoceánicos.

Palabras Clave: Océano Índico, Ratnakara, poscolonialismo, transnacionalismo. 
Compared to the Mediterranean and the Atlantic, the Indian Ocean, as a solid area of research has only began to gain impetus since the 1980s. Current debates on the Indian Ocean focus on transnationalism as social scientists, in particular, have gradually understood the simultaneously unifying and fragmentary essence of this maritime space.

Accordingly, the geographical area of research comprised by the South-West Indian Ocean, that is East and South Africa, Mauritius, India and Sri Lanka, has been construed as a rhizomatic cultural and historical arena endowed with a natural sense of transnationalism rather than as discrete geographical regions (Hofmeyr 2010; Kearney 2004; Moorthy \& Kamal 2010; Simpson \& Kresse 2007). Historian Markus P.M. Vink singles out certain key terms in his landmark article on the "new thalassology" in Indian Ocean studies. Henceforth, porousness, permeability, connectedness, flexibility, and openness of spatial and temporal boundaries must inform any contemporary study of the area (Vink 52). Taking into account the danger of overlooking the flexible internal and external boundaries, scholars from various disciplines seem to agree on the need to regard the Indian Ocean as a unifying factor, connecting peoples and events across the ocean but at the same time as a divisive element that fragments and distances communities through space and time (Bose 25-26). These paradoxical notions of integration and fragmentation feature in much recent discussion of Indian Ocean writing, despite the fact that this area of research has yet to receive the critical attention from literary or cultural scholars that it deserves. No doubt this is in part due to its "messiness" as political frontiers fail to contain or explain with sufficient rigour the fluidity of its borders and the connectedness of its communities. However, literature revels in messiness as can be appreciated by the academic articles and examples of creative writing published in this special issue. Indeed, the inherent flexibility and porousness of the region bring to the fore the undertones of problems which are produced by myths of belonging: who belongs where and how long it takes a community to belong. The monsoon winds brought travelers and merchants across the Indian Ocean centuries before the Europeans even set foot in Africa. The Indian presence on the Swahili coast was substantial and merchants from the subcontinent began to acquire an increasingly important role in the commercial and financial life of Zanzibar. Under the British colonial machinery, Indians were recruited to build the railway in East Africa and indentured labour was required for the sugar plantations of Mauritius and Natal, thus mixing with the established African population. Many Indian Ocean writers both celebrate the hybridity of the region but also bear testimony to the inevitable friction and competition among the diverse ethnicities, in part triggered by the racial hierarchy instigated by the British. The socio-political, linguistic and religious ethnic mingling has given rise to an exciting new literature that this special issue acclaims.

Indian Ocean imaginaries are configured around Prestholdt's "basin consciousness" (454). To put it differently, in Indian Ocean fiction writing, national affiliations are modulated against an oceanic canvas that, in a rather nostalgic manner, revives the regional ethos of the maritime world of the past. However, this is a relatively recent development of Indian Ocean consciousness which is concomitant with the emergence of the new social imaginaries that have been shaped 
as a consequence of the discovery of oil in the Gulf, the development of air travel and the increasing globalized nature of inter-state relations. The creation of the Indian Ocean Rim Association for Regional Cooperation (IOR-ARC) epitomizes Prestholdt's "basin consciousness" since only "sovereign states of the Indian Ocean" (Prestholdt 451) can be members. The oceanic orientation of IOR-ARC recovers the pre-colonial regional sensibility that viewed the Indian Ocean as a collective and shared geography.

Colonialism altered the perception of the Indian Ocean as a unifying, albeit contentious, geographical whole by imposing national closures that permeated the future movements of independence. As Prestholdt observes, the decolonization process of the area was punctuated by the nation-oriented ideology of empire and, as a result, the independent nations that emerged out of the political struggle for liberation had to re-negotiate their Indian Ocean spatiality. In Prestholdt's own words, "in the decades after independence the new nations of the Indian Ocean rim developed allegiances that hinged on corporate experiences of colonialism and a mutual respect for national sovereignty" (451). The sovereignty of the nationstate stood at the core of the alliances forged in the 1955 Bandung meeting and the Afro-Asian People's Solidarity Conference. A recognition of a shared experience of colonialism did not entail, as Gupta insightfully notes in "The Song of the Non-aligned World: Transnational Identities and the Reinscription of Space in Late Capitalism," a recognition of a shared history. Nonetheless, a profound recognition of the existence of a shared history is precisely what emanates from Indian Ocean literature which is necessarily configured as a transnational performance. It is also through the lens of transnationalism that we evaluate our academic trajectories.

In 2010 we founded the research group Ratnakara: Indian Ocean Literatures and Cultures and by means of several research projects we have made a significant contribution to the opening up of the area of Indian Ocean literary analysis. We first began by arguing for the need to overcome the celebratory tone with which the phenomenon of hybridity in post-colonial studies is approached and to observe and question narrative silences and tensions in Mauritian and East African writing, which prove the deep cultural affinity, which dates from the days of slavery, between East Africa and the Indian Ocean (Hand 2009 \& 2010a). As the title of this first research project disclosed, Cartographies of Indianness in Indian Ocean Literatures. Memory, Affiliation, Trauma, we sought to re-configure the concept of "Indianness" through the lens of traumatized memories. This was a reaction against the excessive celebration of multiculturalism that epitomized discourses of "Indianness" within, for example, the Caribbean space. From a non-essentialist perspective that prioritized individual experiences over the communal performance of uncontested multiculturalism, we counteracted the utopian Pan-Indian Oceanness expressed by Jules Herman, R.E. Hart and M. de Chazal. A re-assessment of heritage, culture, memory, social and linguistic identity in the geographical areas of East Africa, Madagascar, Reunion, Mauritius and the Comoro Islands thus ensued.

In our next project, Relations and Networks in Indian Ocean Literatures, we proceeded to show that the term "diaspora" -so often associated with success stories- sits uneasily in the Indian Ocean. The Indian Ocean has been home to failed 
diasporas, especially those people who have not embarked on projects of cultural memory and constructing homelands. Moreover, certain themes like purity and pollution have had to be reinvented. We showed that Indian diasporic communities cannot be dealt with in an impressionistic or essentialist fashion and, at the same time, have emphasised the transoceanic connections that bind Indian Ocean people together (Hand 2015, 2010b \& 2011; Khoyratty 2011; Pujolràs-Noguer 2015).

The previous research which, as indicated before, focused on the literatures and cultures -in particular of the people of Indian origin- of Kenya, Zanzibar and the Mascarene Islands, showed us the need to expand on this work by incorporating the South African Indian community into the corpus. Thus we have corrected the imbalance in this area and contributed to the growing body of critical work on the South Asian diaspora in the Western Indian Ocean -a still relatively underresearched area. The South African Indian community has invariably been omitted from studies of the South Asian diaspora so our research has established a dialogic discourse amongst the Indian Ocean peoples and, in particular, amongst the people of Indian origin in East and South Africa and Mauritius. Therefore, while we continued to focus on the South Asian diaspora communities in the Indian Ocean world, we took our previous research findings in hybridity one stage further by exploring the sociality and patterns of connectedness that are being forged between diverse communities in South Africa. The Indian community in South Africa followed a different settlement pattern from Mauritius or Kenya, and yet, we located the specific South African Indian experience as an integral part of the overall Indian Ocean experience.

One major objective of this project was to gradually fill in the gap in Indian Ocean studies through -amongst other activities- the publication of a volume on South African Indian writers (Hand \& Pujolràs-Noguer 2018). Writers of Indian origin have largely been omitted from studies of South African literature and, curiously enough, their work rarely finds its way into studies of the cultural productions of the South Asian diaspora. The shady area they occupy in terms of national belonging links them to East African writers of South Asian origin, whose credentials have frequently been questioned. Arlene A. Elder (1992) provides a careful reading of the short stories of Ahmed Essop, together with a discussion of the novels of the Ugandan Asian authors, Bahadur Tejani and Peter Nazareth. In his mammoth study The Literature of the Indian Diaspora: Theorizing the Diasporic Imaginary (1997), Vijay Mishra claims that in South Africa "the multiracial disappeared under the politics of apartheid, [so] the writing of the Indian diaspora remained muted, and politically less agonistic" (59). Mishra devotes a page to the work of Ahmed Essop, who, he claims, offers a critique of South African supremacist ideology; but, like Elder, Mishra fails to mention any other South African Indian writer in his study. Naturally, this shows that in the late twentieth century few South African writers of Indian origin had been able to publish their work, a reminder of the political restraints on production and publication during the apartheid era.

More recent studies engage with what Mariam Pirbhai calls a "broadening of [post-apartheid South Africa's] literary frontiers" (70). She classifies the writing into two waves as well as two generations of diasporic writing in South Africa: the 
writing that responded to apartheid and that of the post-apartheid years, after the demise of the regime in 1990 (Pirbhai 70). She claims: "It is in the later fiction that ethnic self-assertion is approached more forcefully" (71). Pallavi Rastogi agrees that "there is a direct and determinate relationship between politics and identity in South African Indian writing" (9) but argues that a South African identity is the primary affiliation, even though Indian idiosyncrasies are not wholly erased (Rastogi 9). Ronit Frenkel similarly tackles the thorny category of "race," which, she claims, still lies at the root of contemporary sociocultural divisions in post-apartheid South Africa. Her study "destabilise[s] such taxonomies by exploring what they mean and how they continue to inform culture" (6).

Therefore, we realized that, while critics were beginning to examine the recent writing of South African Indians, with the notable exception of Govinden's sensitive study of South African Indian women writers (Govinden 2008), no study had provided a comprehensive analysis of the patterns of connectedness that were being forged between diverse communities in South Africa; indeed, South African Indian writers are often still ignored in mainstream publications. While it is clear that racial and class categories could not be ignored in a country with a recent history of brutal exploitation and statutory oppression, many studies explored what we called "relations and networks" in the post-apartheid era, hence delineating a social geography in which subjectivities were being constructed beyond -and despite- constraining racial and ethnic parameters. Although we observed that scholars such as Gaurav Desai, Pallavi Rastogi, and Ronit Frenkel had engaged in an exploration of relational subjectivities in their work, thus already adhering to a "relations and networks" paradigm, they had never formally conceptualized the term. Our "relations and networks" framework should therefore be acknowledged as an attempt to foreground a methodology whereby ethnicity, class, and gender inextricably coalesce to map out the national space of post-apartheid South Africa. Through the analysis of a selection of writers, emerging as well as leading voices of the "new" South Africa, we managed to bring to the fore the sociality and patterns of connectedness that were being forged between South Africa's hitherto divided communities. Our starting point was that literature inflected productions and performances of identities in relation to the long history of trade and encounter that had been conceptualized largely from the perspectives of economic history and geographical studies.

Stemming from a Foucauldian perspective on subjectivity which measures the subject as an active participant in a strategic interplay of power relations, in Relations and Networks in South African Indian Writing -the visible product of the research conducted by the Ratnakara members-we fostered consideration of SouthSouth subjectivities by strategically locating South African Indian literature within the relations and networks paradigm that shapes the Indian Ocean world and its cosmopolitanisms. These South-South subjectivities, which speak of relations and networks across the Indian Ocean, coexist with and also pre-date colonialism. Henceforth, we claimed that the experience of history as embedded in literary texts evinced an unceasing transformation of self. The literary texts which were examined -Aziz Hassim's The Lotus People and Revenge of Kali, Achmat Dangor's 
Kafka's Curse, Shamim Sarif's The World Unseen, Ronnie Govender's Black Chin, White Chin, Imraan Coovadia's The Wedding and High Low In-Between, Ashwin Singh's To House, Dr Goonam's Coolie Doctor and Fatima Meer's Prison Diary: One Hundred and Thirteen Days 1976 among others- displayed a varied range of mechanisms whereby institutional bodies, desires, and discourses were deconstructed in order to lay out the script for an aesthetics of resistance. It was paramount for us to demonstrate that understanding and situating the South African Indian experience as a constitutive component of Indian Ocean thalassology required a more nuanced investigation of the relationship between self and other than what had been elicited so far. We successfully concluded that the South African Asian community, despite having followed a different settlement pattern from Mauritius or Kenya, had to take its place as part of the Indian Ocean experience. Moreover, we have proved that a thorough study of South-South subjectivities can throw light on alternative ways of being in the world.

The re-assessment of "Indianness" initiated in our first project was thus consolidated in this second project in which not only narratives by authors of Indian origin from East Africa and Mauritius were analysed, but also narratives by authors of Indian origin from South Africa. All these narratives reflected individual cultural and memory projects while at the same time they manifested the transoceanic connections that unite the peoples of the Indian Ocean rim (Hand 2018a; PujolràsNoguer 2018 \& 2019).

As outlined in the previous paragraphs, our research projects so far were entirely focused on fiction. Notwithstanding, in our next project, The Aesthetics of Remembering: Empathy, Identification, Mourning, we branched off into life writing. The reason behind this generic turn is the realization that the "re-membering" act that characterized the narrative development of Indian Ocean fiction writing had to be consolidated alongside the many autobiographical accounts of individual and/or communal memories. The first part of the title of our project, The Aesthetics of Remembering, is a straightforward allusion to the theoretical paradigm that we have created as a means to explore the diverse personal narrations of members of the South Asian diaspora in South Africa, East Africa and survivors or descendants of survivors of the partition of India (Hand 2018b; O'Connor 2018). The location of these life stories at the intersection of national and global exclusion rendered them particularly sensitive to the Affect Theory concepts of "in-between-ness" and "accumulative besided-ness" (Gregg \& Seigworth 2010). As Williams (1985) would have it, these individual narratives delineate structures of feeling, that is to say, lived experiences, shared by communities geographically distant from one another. Empathy lies at the centre of our aesthetics of remembering methodology to the extent that we have proved how reading and creative writing foments an empathetic relationship with the marginalized subject unveiling her/his life. This aesthetics of remembering allows us also to re-assess the very concept of "empathy" through the lens of postcoloniality. Ultimately, the "aesthetics of remembering" explores the space created by the intersectionality of what we discovered to be three recurrent themes in studies of postcolonial expressions of selfhood: the above mentioned empathy, identity and mourning. 
Postcolonial literary criticism has recently focused its scrutiny on life writing, that is the memoirs and experiences of citizens from former colonized countries. Autobiography has long featured as a subgenre of literary criticism but its emphasis on the Enlightenment persona, a rational, sovereign subject, usually male and invariably white, marginalized those people whose life stories were regarded as inherently inferior and of little interest, such as slaves, indentured labourers or simply people inscribed as being racially inferior. The proliferation of postcolonial theories has widened the understanding of selfhood and has challenged the notion of a unified, unique selfhood which could express universal human nature (Anderson 5). The very term 'autobiography' has tended to be relegated to the work of Western authors and has been replaced with the more inclusive category of 'life writing' (Whitlock 3). The changing nature of identity formations has contributed to the continued exploration of and experimentation in the generic forms of life writing, autobiography and memoir (Driver \& Kossew 2014). In this way, the Enlightenment subject is decolonized and space is made for former minor genres to flourish. The inclusion of formerly overlooked writing subjects and the straining at the seams of the genre has brought about a need to read across national borders.

Postcolonial communities are nowadays transnational in outlook and filiation, which has encouraged scholars to propose new strategies for reading and analyzing these cultural productions. Recent critical work on life writing by people who have directly or indirectly experienced colonialism has often focused on traumatic experiences because their lives have been shaped by the shifting boundaries of what it actually meant to be human in these societies (Craps 2013; Hassan \& Álvarez 2013 and Whitlock 2015). Craps highlights the traumatic experiences of non-Western or minority groups, which have been ignored in favour of the universal validity of definitions of trauma and recovery that have developed out of the history of Western modernity. The special issue of Biography edited by Hassan \& Álvarez engages critically with postcolonial studies and autobiography by exploring the continued relevance of the term postcoloniality. Whitlock's comprehensive study includes insightful analyses of powerful testimonies of social injustices and oppression. Lives that are situated at the social, political, and cultural margins of the national and the global need to be represented but this is itself problematic, as Gayatri Spivak eloquently reminds us. The danger can be reduced to how the Western critic can explore the narratives of particular lived situations or personal histories which may remain trapped within the logic of the colonial past without fossilizing or essentializing them. The postcolonial present itself needs to be approached with extreme caution. The specters of colonialism may continue to haunt the contemporary, but we have reconsidered the critical preoccupations of subjecthood and resistance through careful readings of testimonials, memoirs, and political biographies as well as creative writing. The texts that we explored are selfconsciously focused on narrating lives in their proximity to physical and/or social death conditioned by the legacies of colonialism. However, we went beyond the pessimism of the past and explored how the texts chosen moved forward. From our perspective, fictionalised narratives of atrocities are to be treated similarly to the more expected first-person memoirs as we consider that human rights violations 
can be brought closer to readers when victims or survivors become real people with names and backgrounds rather than just statistics in a roll call of horror.

The recovery and mediation of cultural practices which have been and may continue to be subjected to institutional forgetting is a key player in the struggle between hegemonic culture and minorities (JanMohamed \& Lloyd 8) thus not only is archival work essential to the critical articulation of minority discourse but also the discovery of hidden testimonies, especially from women survivors. As an attempt to approach women survivors who had been victims of gender violence, we conducted two creative writing workshops in Kampala, Uganda. The first took place at the premises of Isis-WICCE (Women's International Cross-Cultural Exchange), an extremely active feminist organisation whose members are the recipients of harrowing stories from women who have been abused, both sexually and psychologically. The second creative writing workshop was organized together with Femrite, the association of Ugandan women writers and its focus was on life writing. These two creative writing workshops provided us with autobiographical texts that have contributed enormously to reinforce our theoretical paradigm called "Aesthetics of Remembering" and it also proved that writing can be a decisive component in the disclosure of invisible traumas. Equally important, it demonstrated that the transference from traumatic experience to narrative granted the traumatized victim an audience willing to listen to her story. The volume entitled In/visible Traumas: Healing, Loving, Writing, a recollection of the narratives produced in the creative writing workshop, is the substantial testimony of traumatized lives that are an intrinsic and indisputable part of Indian Ocean imaginaries (Pujolràs-Noguer \& Hand, 2018).

The research that resulted from this third project led us to the recognition of a deep-seated "communal" self as a key factor in the functionality of the aesthetics of re-membering, which brings to the fore the rhizomatic nature of the Indian Ocean cultural geography. This was the basis for our ongoing research project, Rhizomatic Communities: Myths of Belonging in the Indian Ocean World, which aims at examining the life writing of communities that are numerically minorities in their adopted homelands and which debunks the myth of belonging as for them there can be no unilateral sense of belonging. Moreover, and as we could corroborate in our previous research projects, the Indian Ocean situation belies any sense of a unified, national belonging. We claim that these myths of belonging, once deconstructed, can only expose the undertones of problems experienced by ethnic minorities, people marginalized through disease and poverty and persons forcibly expelled from their homeland but at the same time can reveal similar patterns of reliance on cultural artefacts as survival strategies.

The archival and textual work so far conducted had been monitored by a focus on the "individual", that is to say, on how specific human beings performed their identities within a larger community structure. However, we realized that this individual-focused line of analysis began to falter and, therefore, could not be fully sustained, since a deep sense of community seamed through the individual identity performance. In other words, the communal self, pervaded in a manner that challenged but simultaneously guided the formation of a satisfactory, albeit 
deeply dis-unified identity, through conciliatory acts of empathy via calculated episodes of mourning.

Critical work on the specificities of a potential corpus of "communal life writing" is practically inexistent. Our research into this area has identified one sole community which is treated under the lens of a forgotten postcolonial minority: the Chagossian people in Mauritius. Sociologists and anthropologists have studied the Chagossians (Jeffery \& Vine 2011; Johannessen 2010) and there are studies on literary representations of them (Bragard 2008; Ravi 2010) but to date no study has explored the "communal" life writing of these human collectives. Davis et al remind us that "personal and collective memory creates a space where fact, truth, fiction, invention, forgetting, and myth are so entangled as to constitute a renewed form of access to the past" (11). We agree with them when they claim that "individual identity is constituted in relation to family and national history" (David et al 13) which upholds our aim to focus on the life writing of communities, in order to debunk the myth of belonging. This dismantling of the myth of belonging is an attempt to denounce the still pervasive myth of origins that surreptitiously intrudes in identity constructions and, at the same time, enhances the "in-betweenness" that defines a rhizomatic understanding of historical, socio-cultural and national affiliations. Glissant (1997) has long disclosed the multiplicity of cultural identities that configure individual identities. Thus, our point of departure is that life stories express the need to belong, but they highlight the fact that there is no unilateral sense of belonging. Likewise, and considering the traumatic essence enveloping these life stories, we should add Leigh Gilmore's assertion that "Trauma is never exclusively personal, it always exists within complicated histories, both individual and collective" (885). The Indian Ocean, as has been emphasized throughout this article, is construed as a rhizomatic cultural and historical network endowed with a natural sense of transnationalism rather than as discrete geographical regions (Kearney 2004; Simpson \& Kresse 2007; Moorthy \& Kamal 2010). The three axes of our project are delineated by the three communities we have selected: The Chagossian community, the communities resulting from the Eastern Partition of India and the South African HIVIAIDS community.

The Chagossian community of Mauritius suffered the pain of deportation and the prohibition of a legal recuperation of the homeland together with the added complication of the creation of a Marine Reserve and the suggestion that a return of the people would somehow harm the environment and provoke more climatic change on an already delicate ecosystem. Myths of a lost paradise notwithstanding, Chagossians have fought to promote and preserve their culture through highlighting various elements of material culture, such as food and séga music and dancing. Remembering and writing their experiences works as a great therapy for building up self-esteem as a people and for claiming a space in the Indian Ocean imaginary. However, this claim for visibility in the Indian Ocean imaginary, begs the following question: to what extent is the profound sense of community that binds the Chagossian experience formulated upon the loss of their homeland? The article, "The Myth of the Empty Territory. The Tragedy of the Chagos Islanders" included in this volume, seeks to untangle the diverse modes of coercion and persuasion that a forceful communal self can inflict upon the marginalized individual. 
The second axis, narratives of the Eastern Partition of India, is a continuation of the work carried out in the previous project. Following Paul John Eakin's assertion that "we remodel our pasts to bring them into sync with our sense of our selves and lives in the present" (94), we aim to trace this conjuncture of past and present, especially in remembering traumatic events/histories. The "aesthetics of remembering" we coined in the previous research project, functions as an umbrella concept within which to (re)consider the aftermath of a traumatic event like the Partition of India. The role of autobiographies, testimonials, memoirs, and fictionalized first-person narratives, through which the event is itself (re)written, (re) imagined and memorialized, become the ground upon which the "history" of the event and a production of the "past" are constructed. In this new project, we will be seeking to answer the following questions: What happens to our understanding of the imbrication of the present in the reconstruction of the past? How do we analyze and understand memory as a "lived project"-structured and reconstructed not only through the anxieties of the present but also through the genres of recollection (memoir, testimonials, autobiographies, and fictionalized first-person narratives, photographs and foodways)? How does the communal self impinge on the process of self-creation of women that survived the Eastern Partition of India? In what representational mode(s) does the experience of communal marginalization and oppression of Dalits intertwines with the national trauma of Partition?

Our third axis is South Africa and specifically the people affected by HIV/ AIDS who constitute a community of ostracised, stigmatized persons. The slow, incalculable devastation that HIVIAIDS wreaks proves this disease to be much deadlier than the famines, the wars, the corruption, the lack of clean water and so forth that scourge the country as it amplifies the damage at the same time that it undermines the ability to respond to these disasters because it targets the young and productive. In recent years, however, people and governments are becoming more engaged in their response to AIDS and this is visible in the growing body of personal narratives by AIDS sufferers. People affected by HIV/AIDS struggle to underline their presence in the national effort to build the New South Africa, a nation purposely construed upon inclusion parameters as an aftermath to the border-creating apartheid machine. So, the question to be confronted is: what representational strategies allow for the maimed bodies of HIV/AIDS sufferers to be integrated as an intrinsic part of the celebratory body politic of the Rainbow Nation?

Some of the questions put forward in our current project, Rhizomatic Communities: Myths of Belonging in the Indian Ocean World, are, if not completely, partially answered in this Special Issue on Indian Ocean Imaginaries. By reading this first article in which an academic trajectory modelled around the Indian Ocean has been outlined, the one experienced by the Ratnakara Research Group, one might erroneously conclude that, from a literary and cultural studies perspective, little remains to be explored in this geographical area. This is, of course, a blatant fallacy. It is specially in the literary and cultural arena that Indian Ocean studies are presently thriving. From a historical standpoint, Prestholdt affirms that "the Indian Ocean port city is practically a memory, yet the cosmopolitan ideal that it evokes is increasingly relevant to our world" (455). Feeding on Prestholdt's assertion, and 
from a literary and cultural positioning, we claim that the memory of the Indian Ocean port city and the cosmopolitan ideal that it evokes metamorphose into the rhizomatic community that has been aesthetically re-produced in Indian Ocean writing. Rhizomes, as Glissant suggestively infers, are endowed with an endless capacity for expansion and an instinctual resistance to closure. So, much remains to be explored in this ever expanding Indian Ocean rhizome.

Reviews sent to author: $15 / 12 / 2020$

Revised paper accepted for publication: 29/01/2021 


\section{WORKS CITED}

Anderson, Linda. Autobiography. Routledge, 2001.

BAARs, Jan. "Critical Turns on Aging, Narrative and Time." International Journal of Aging and Later Life. 7/2 (2012):143-165.

Bose, Sugata. A Hundred Horizons: The Indian Ocean in the Age of Global Empire, Harvard University Press, 2006.

Bragard, Véronique. "Murmuring Vessels: Relocating Chagossian Memory and Testimony in Shenaz Patel's Le Silence des Chagos", 'L'ici et l'ailleurs': Postcolonial Literatures of the Francophone Indian Ocean. e-France: an on-line Journal of French Studies. 2 (2008): 132-147. https:// www.reading.ac.uk/web/files/e-france/Bragard.pdf.

Craps, Stef. Postcolonial Witnessing: Trauma Out of Bounds. Palgrave Macmillan, 2013.

Driver, Dorothy \& Sue Kossew. "Re-framing South African Life Narratives" Life Writing 11/2 (2014): 155-158.

Eakin, Paul John. Writing Life Writing. Narrative, History, Autobiography. Routledge, 2020.

Elder, Arlene A. "Indian Writing in East and South Africa: Multiple Approaches to Colonialism and Apartheid." Reworlding: The Literature of the Indian Diaspora. Emmanuel S. Nelson (Ed.). Greenwood, 1992. 115-139.

Frenkel, Ronit. Reconsiderations: South African Indian Fiction and the Making of Race in Postcolonial Culture. University of South Africa Press, 2010.

Gilmore, Leigh. "Trauma and Life Writing." Encyclopedia of Life Writing: Autobiographical and Biographical Forms, vol. 2. Margaretta Jolly (Ed.). Fitzroy Dearbon, 2001. 885-887.

Glissant, Édouard. Poetics of Relation. Trans. Betsy Wing. University of Michigan Press, 1997.

Govinden, Devarakshanam Betty. Sister Outsiders: The Representation of Identity and Difference in Selected Writings by South African Indian Women. University of South Africa Press, 2008.

Gupta, Akhil. “The Song of the Non-aligned World: Transnational Identities and the Reinscription of Space in Late Capitalism.” Cultural Anthropology, 7/1 (1992): 63-79.

Gregg, Melissa \& Gregory J. Seigworth (Eds.) The Affect Theory Reader. Duke University Press, 2010.

Hand, Felicity. "La isla de Mauricio: un laboratorio de hibridación." Studia Africana. Número monográfico sobre Mauricio, 19 octubre (2009): 103-108.

Hand, Felicity. “Untangling Stories and Healing Rifts: Abdulrazak Gurnah's By the Sea.” Research in African Literatures, 41/ 2 (2010a): 74-92. https://doi.org/10.1353/ral.0.0246.

Hand, Felicity. The Subversion of Class and Gender Roles in the Novels of Lindsey Collen. Edwin Mellen Press, 2010b.

Hand, Felicity. "Impossible Burdens: East African Asian Women's Memoirs." Research in African Literatures, 42/3 Fall (2011): 100-116. https://doi.org/10.1353/ral.2011.0065.

Hand, Felicity. "Coping with Khandaanity in Diaspora Spaces: South Asian Women in East Africa." Revista Canaria de Estudios Ingleses, 70 May (2015): 13-40.

Hand, Felicity. "Picking Up the Crumbs of England': East African Asians in Yasmin AlibhaiBrown's Autobiographies." The Journal of Commonwealth Literature, 53/1 (2018a): 61-77. https://doi.org/10.1177/0021989416652646. 
Hand, Felicity. "Narrative Empathy in Dr. Goonam's Coolie Doctor and Zubeida Jaffer's Our Generation." Life Writing, 15/4 (2018b): 561-576. https://doi.org/10.1080/14484528.2018.1426969.

Hand, Felicity \& Esther Pujolràs-Noguer (Eds.). Relations and Networks in South African Indian Writing, Brill Rodopi, 2018. https://doi.org/10.1163/9789004365032.

Hassan, Salah D. \& David Álvarez (Eds.). "Baleful Postcoloniality” Biography 36/1 (2013).

Huggan, Graham \& Helen Tiffin. "Green Postcolonialism.” Interventions. International Journal of Postcolonial Studies. 9/1(2007): 1-11. https://doi.org/10.1080/13698010601173783.

Kearney, Milo. The Indian Ocean in World History. Routledge, 2004.

Khoyratty, Farhad. "From the Ocean with a Short Memory: The Bollywood Courtesan as an Old/ New Myth of Origin for Mauritian Muslims." Repenser les mythes fondateurs et l'ecriture de l'histoire dans l'espace Océan Indien ed. Eileen William Wanquet and Mohamed Aït-Aarab, Océan Edition, 2011. 145-156.

Hofmeyr, Isabel. “Universalizing the Indian Ocean” PMLA, 124/ 3 (2010): 721-729.

Janmohamed, Abdul \& David Lloyd. "Toward a Theory of Minority Discourse" The Nature and Context of Minority Discourse. Cultural Critique 6 (1987): 5-12.

Jeffery, Laura \& David Vine. "Sorrow, Sadness, and Impoverishment: The Lives of Chagossians in Mauritius". Eviction from the Chagos Islands: Displacement and Struggle for Identity against Two World Powers. Sandra Evers \& Marry Kooy (Eds.). 2011. 83-102.

Johannessen, Steffen F. "From Socialist Uprising to Cultural Genocide: the Emergence of Traditions in Chagossian Struggles for Repatriation". Tradition Within and Beyond the Framework of Invention: Case Studies from Mascarenes and Japan. Susanne Klien \& Patrick Neveling (Eds.). Zentrum für Interdisziplinäre Regionalstudien Vorderer Orient, Afrika, Asien der Martin-Luther-Universität Halle-Wittenberg, 2010. 69-104.

Mishra, Vijay. The Literature of the Indian Diaspora: Theorizing the Diasporic Imaginary. Routledge, 2007.

Moorthy, Shanti \& Ashraf Jamal (Eds.). Indian Ocean Studies. Cultural, Social, and Political Perspectives, Routledge, 2010.

Neyrat, Frédéric. The Uncontestable Earth: An Ecology of Separation. Fordham University Press, 2018.

O'Connor, Maurice. "Exploring the Hindu/Muslim Divide Through the Partition of Bengal." Revista Canaria de Estudios Ingleses. 76 (2018): 45-56.

Pirbhai, Mariam. Mythologies of Migration, Vocabularies of Indenture: Novels of the South Asian Diaspora in Africa, the Caribbean, and Asia-Pacific. University of Toronto Press, 2009.

Prestholdt, Jeremy. "Locating the Indian Ocean: Notes on the Postcolonial Reconstitution of Space." Journal of Eastern African Studies. 9/3 (2015): 440-467.

Pujolràs-Noguer, Esther. "Between Memory and Desire. The Historical Novel as a Shadow Genre in Abdulrazak Gurnah's Desertion” CLIO 45/1 (2015): 41-65.

Pujolràs-Noguer, Esther. "Desiring/Desired Bodies: Miscegenation and Romance in Abdulrazak Gurnah’s Desertion” Critique. Studies in Contemporary Fiction. $59 / 5$ (2018): 596-608. https:// doi.org/10.1080/00111619.2018.1459456.

Pujolràs-Noguer, Esther. "Imperially White and Male. Colonial Masculinities in M.G. Vassanji's The Book of Secrets (1994) and Abdulrazak Gurnah's Desertion (2005)" Interventions. Journal of Postcolonial Studies. 21/1 (2019): 131-149. https://doi.org/10.1080/1369 801X.2018.1487323. 
Pujolràs-Noguer, Esther \& Felicity Hand (Eds.). In/visible Traumas. Healing, Loving, Writing, UAB Digital Deposit, 2018. https://ddd.uab.cat/record/195164 also published by Femrite, Uganda, 2019.

Rastogi, Pallavi. Afrindian Fictions. Diaspora, Race, and National Desire in South Africa. Ohio State UP, 2008.

Ravi, Srilata. "Grieving Islands: History, Memory and the Chagossian Tragedy". Eyes Across the Water: Navigating the Indian Ocean. Pamila Gupta, Isabel Hofmeyr \& Michael Pearson (Eds.). UNISA Press, 2010: 344-360.

Simpson, Edward \& Kai Kresse (Eds.). Struggling with History. Islam and Cosmopolitianism in the Western Indian Ocean, Hurst \& Company, 2007.

VINK, Markus P.M. "Indian Ocean Studies and the 'New Thalassology" Journal of Global History, 2 (2007): 41-62.

Whiтlocк, Gillian. Postcolonial Life Narratives. Testimonial Transactions. Oxford University Press, 2015.

Williams, Raymond. The Country and the City. Chatto and Windus, 1985. 